\title{
DEFINING PERUVIANS AS A PROBLEM: ETHNIC PROJECTS AND RESISTANCE AT A
}

\author{
JAPANESE ELEMENTARY SCHOOL
}

\author{
Robert Moorehead
}

College of DuPage

An earlier version of this paper was published in 2014 in Damunhwawa Ingan [Multicultural Studies] 3(1):31-60 (http://www.dbpia.co.kr/Journal/ArticleDetail/3478842) as proceedings from the conference "The Ins and Outs of Migration: Migration and the Life-World in Global Asia," held at the Catholic University of Daegu, Korea, in May 2014.

\begin{abstract}
I argue that some Japanese elementary school practices, such as having foreign parents sign a loyalty oath and repeatedly questioning the parents about their migration plans, constitute an ethnic project that defines these parents as disloyal aliens who are unwilling to adapt to Japanese cultural norms. In response, the foreign parents limit their willingness to assimilate. Based on ethnographic fieldwork at a public elementary school in central Japan that has more than 50 foreign children, the majority of whom are Peruvians of Japanese descent, I explore the context of reception in the school, including teacher-parent relations, teachers' expectations, their complaints, and their questions about the parents' commitment to living in the host country. I ask what is the nature of the relationship between Japanese teachers and foreign parents? How are school practices influencing the context of reception, and how is that context impacting foreign parents' sense of belonging in Japan? I conclude by discussing potential impacts, including the reproduction of existing inequalities in this immigrant population.
\end{abstract}

KEYWORDS: Japan, Peruvians, immigration, education, ethnic project

DRAFT - Please do not cite without permission of author. 
In 1903, W.E.B. Du Bois famously asked of black Americans' experiences of racial subjugation in the United States, "How does it feel to be a problem?" (p. 1). This question resonates more than 100 years later, in another country and on another continent, as we examine tensions in the relations between native-born teachers and foreign parents at Shiroyama Elementary School. ${ }^{1}$ This public school in central Japan has approximately 50 students from foreign families, many of whom are Peruvian. In this setting, school policies and teachers' actions call into question foreign parents' motives for migration and their loyalty to the host country. This reception creates an environment in which being foreign is seen as a problem (Du Bois 1903; Lewis 2003). Across Japan, tens of thousands of foreign children are attending public schools (MEXT 2013); however, foreign residents are less than two percent of the Japanese population, and popular notions of Japanese identity position foreigners as permanent outsiders in Japan. In this context, what is the nature of the relationship between Japanese teachers and foreign parents? How are school practices influencing the context of reception for foreigners, and how are foreign parents responding to this reception? Also, what are the potential future impacts on inequality for these foreign groups?

Based on participant observation and interviews with parents, teachers, and administrators, I explore the context of reception for Peruvian parents at Shiroyama Elementary. I examine teachers' relations with the parents, including teachers' expectations, complaints, and questions about Peruvians' commitment to living in Japan. I highlight the mechanics of how teachers are able to create social distance (Blumer 1958; Memmi 1968; Omi and Winant 1994) between themselves and Peruvian parents through the use of an ethnic

\footnotetext{
${ }^{1}$ In this article, informants' names and place names are pseudonyms to protect informants' identities.
} 
project (Moorehead 2012, 2013; Omi and Winant 1994) that defines Peruvian parents as disloyal aliens who are unwilling to adapt to life in Japan and who must prove their loyalty to the host country. The concept of an ethnic project is a Japan-specific adaptation of Omi and Winant's (1994) racial project that foregrounds the role of ethnicity in teachers' explanations of the relationships between foreigners and Japanese. Omi and Winant (1994:56) define a racial project as "an interpretation, representation, or explanation of racial dynamics, and an effort to reorganize and redistribute resources along ... racial lines." I use the term ethnicity, and not race, to better fit the Japanese context, where notions of group membership extend beyond race to include shared ancestry, culture, and nationality. This examination also reveals how the teachers' ethnic project may structure paths to future inequality by producing counterhegemonic resistance (Tsuda 2000; Williams 1977) by the foreign parents, who state they will hold off on assimilating further until they receive greater acceptance as members of Japanese society. This resistance, in turn, may fulfill the negative expectations of nativist teachers, resulting in a cycle of hostility (Bonacich 1973; Takenaka 2004).

This tension between foreigners and the native-born has the added dimension that many of these foreigners are Nikkeijin (foreigners of Japanese ancestry) who migrated from South America to Japan with their Japaneseness as key part of their ethnic identity (Takenaka 2004, 2008; Tsuda 2003, 2010). The Japanese state has encouraged this perspective by sustaining diasporic ties with ethnic associations in South America, and by creating a special visa category only for the Nikkeijin and their family members (Takenaka 2004, 2008; Tsuda 2003, 2010). While ethnic return migration is often motivated by migrants identifying with the ancestral homeland, such identification tends to weaken after migration as members of the 
host society reject migrants' claims to a shared ethnic identity (Fox 2007; King and Christou 2010; Takenaka 2014; Tsuda 2009). In the case of the Nikkeijin, such a reception reinforces their status in Japan not as ethnic descendants who have returned to the homeland, but as gaijin (foreigners, outsiders).

That these foreigner-native interactions are occurring at a local public elementary school is important, as host-country schools are key sites for the integration of foreign families into the host society. Positive parent-teacher relationships can encourage foreign parents' trust in the schools, facilitate their sense of belonging in the host society, and help foster more consonant acculturation within foreign families (Kasinitz et al. 2008; Portes and Rumbaut 1996, 2001; Portes and Zhou 1993; Zhou and Bankston 1998). Parent-teacher relations can also reflect the relations of power and domination that define immigrants' status in the host society (Jung 2004). When foreign parents do not meet teachers' expectations of how a (native-born) parent should act, teachers may blame the parents' foreign status and push the parents to prove their commitment to staying in, and adapting to, Japan. In response, the parents recoil at being treated as outsiders and as lesser members of the school community. Through these interactions, foreign parents are learning their place at the school and in Japanese society. As members of a subordinate group, they are coming to expect marginalization (Golash-Boza 2006:33); however, they are also resisting it.

\section{FIELD SITE AND METHODS}

Shiroyama Elementary School is located in the working-class district of Shiroyama, in a city of 75,000 people in central Japan. Many of the district's roughly 700 foreign residents are South American Nikkeijin. Their migration to Japan was made possible by the Immigration 
Control and Refugee Recognition Act of 1990, which created a long-term resident visa for people of Japanese ancestry. Since the law's passage, hundreds of thousands of Nikkeijin have migrated to Japan from South America. By 2007, the number of South American residents had peaked at nearly 394,000, up from only 3,600 in 1985 (Statistical Research and Training Institute 2010). When able to find employment in Japan, the Nikkeijin are often in low-skilled factory positions that provide no opportunities for advancement (Higuchi and Tanno 2003; Takenoshita 2006; Tsuda, Valdez, and Cornelius 2003). Like labor migrants in many countries, the Nikkeijin have few opportunities to transfer their skills to the broader labor market, as they are held back by their limited command of the Japanese language and by discrimination, from which Japanese law offers few protections (Gurowitz 2006).

Many of Shiroyama's Peruvian families migrated as target earners who planned to return to Peru after several years of work. They have since decided to settle in Shiroyama for the foreseeable future, as their children have acculturated to life in Japan and speak Japanese better than Spanish. However, the mass layoffs of foreign workers at the start of the global recession in 2008 reminded the workers of their precarious position in Japan (Higuchi 2010). By the end of 2012, the number of South Americans in Japan had dropped by 36 percent from its 2007 peak, as more than 140,000 had left the country (Ministry of Justice 2013). This mass exodus was accelerated by growth in the Brazilian and Peruvian economies, and by a Japanese government payment to Nikkeijin to return to South America (Ministry of Health, Labour, and Welfare 2009, 2012).

The migration wave back to South America has also reduced the number of foreign students at Shiroyama Elementary School. In 2007, prior to the economic downturn, the 
number of foreign students at the school had peaked at 56 , out of a total student population of roughly 800 . In 2013, only 23 foreign students were attending the school. Nearly all of the school's foreign children are from Peruvian families, with smaller numbers of students from Bolivia, Brazil, China, and the Philippines. Most were born in Japan, and all but a few attended Japanese preschool or kindergarten prior to starting elementary school.

From 2005 to 2007, I conducted participant observation full-time at Shiroyama Elementary. Funded by a Fulbright fellowship, I volunteered as a Japanese-Spanish interpreter, translator, and assistant teacher. While taking ethnographic field notes, I interpreted during parent-teacher meetings, translated messages and school documents, tutored in remedial Japanese and mathematics, and led free Spanish classes on Saturdays. I also conducted intensive interviews with Peruvian and Bolivian parents, and informal interviews with Japanese teachers and administrators. I recorded and later transcribed these interviews, with a research assistant performing the Japanese transcriptions. Since returning to Japan in 2011, I have also made multiple trips to Shiroyama to interview foreign parents and children, meet teachers, and visit the school. I coded the interview transcriptions and field notes using HyperResearch, a qualitative software application, in order to sort the data into "various categories that organize it and render it meaningful from the vantage point of one or more frameworks or set of ideas" (Lofland et al. 2006:200)

In the following section, I examine the nature of parent-teacher relations in Japanese schools and teachers' complaints about Peruvian parents, including teachers' view of the parents as obstacles to their children's assimilation. I also explore teachers' use of written oaths and tests when dealing with Peruvian parents, and the symbolic importance attached to 
Peruvian families' travel to Peru, before examining the impacts on Peruvian parents' assimilation strategies.

\section{PARENT-TEACHER RELATIONS IN JAPANESE SCHOOLS}

Foreigners' reception in the host society can vary from welcoming support to hostility and exclusion, and this reception influences their path of assimilation. In host-country schools, positive relations between teachers and foreign parents can positively impact immigrant families' adaptation to the host society (Kasinitz et al. 2008; Portes and Rumbaut 1996, 2001; Portes and Zhou 1993; Zhou and Bankston 1998). In contrast, negative relations can spur mistrust and resistance, expressed through reactive ethnicities and oppositional identities that reject the values, norms, and identities of the host country (e.g., Portes and Rumbaut 1996, 2001; Tsuda 2000; Williams 1977).

Upon entering Japanese schools, foreign parents discover that Japanese teachers have a broad authority to promote the welfare of their students (Moorehead 2007; Tsuneyoshi 2001). This authority extends into the community, where teachers share "interlocking, overlapping, mutually reinforcing responsibilities" with parents and neighborhood residents (White 1987:73). At Shiroyama Elementary, this collective role manifests itself in calls to former students who now work at a local labor broker that places many foreign parents in nearby factories. Teachers call upon these helpers to relay messages, to explain school practices to the parents, and to help the parents request time off for school matters. As I note later, this act of calling in the community also opens the door to involving others in families' private matters, and limits parents' ability to challenge teachers. Teachers' broad authority also reveals itself in meetings with parents, as teachers ask about parents' lives at home and work, their 
employment status, and even the names and relationships of the people living in their home. They also ask foreign parents how long they intend to stay in Japan, and their plans for visiting their home country. Teachers justify these inquiries on the grounds that such details are related to the children's well-being, and thus fall under the teachers' purview.

In the classroom, professional norms dictate that teachers should treat all children similarly, including having teachers act as if they do not see differences between foreign and Japanese children (LeTendre, Hofer, and Shimizu 2003; Moorehead 2012, 2013; Shimizu 1992, 2001; Shimizu et al. 1999; Tsuneyoshi 1996, 2001). Within this model, teachers are discouraged from openly expressing concerns in class about their students or parents, lest they appear to not be treating students equally. Instead, teachers vent those concerns outside the classroom, in meetings with parents and in children's renrakuchō (a notebook used for sending messages home). The discrepancy between teachers' positive and inclusive front-stage performance (Goffman 1963) inside the classroom, and their more negative treatment of foreign outside the classroom, reveals how teachers construct the ethnic project that defines the parents as disloyal aliens who are unwilling to adapt to life in Japan.

One such instance occurs when Hikaru, a Peruvian boy in the first grade, brings hierba (Peruvian tea) to school in his thermos. As Japanese schools often do not have drinking fountains, students routinely bring a thermos to school. School rules dictate that the thermos may contain only water or unsweetened tea, however Hikaru's teacher, Sasaki-sensei, mistakes hierba for sweet lemon tea. After scolding Hikaru in class for bringing the drink, Sasaki handwrites a three-page note to his mother, in large, bold characters, admonishing her for supposedly violating school rules. 
I am writing you because, no matter how many times I ask you, you do not follow the rules. Today Hikaru had a drink in his thermos that tasted like lemon tea. ... As I told you before, please put only water or tea in his thermos. Please do not give him sweet drinks. ${ }^{2}$

In the same note, Sasaki also reprimands the mother for paying her monthly school fees by giving her son cash. Sasaki later dismisses the mother's reply that she does not know how to arrange for bank transfers in Japanese, and, even if an interpreter were to accompany her to the bank, her lunch break from work is too short for her to travel to the one bank branch the school requires parents to use for the transfers.

\section{QUESTIONING PERUVIANS' COMMITMENT TO LIVING IN JAPAN}

In situations like Hikaru's, teachers treat foreign children as potentially able to acculturate to Japanese norms. In contrast, they treat foreign parents as resisting adapting to life in Japan and as obstacles to their children's successful assimilation. These divergent approaches reflect differences in the teacher-student and teacher-parent relationships. The teacher-student relationship positions children as malleable and receptive to teachers' guidance; however, the teacher-parent relationship treats the parents like finished products who should already know their role. Thus, when foreign parents send their child to school with an unfamiliar type of tea, or with an envelope filled with cash, teachers can complain that the parents are not learning or fitting in. This view of the parents also appears in a tale that the school's interpreter, Kitagawa-sensei, frequently shares. In the tale, Kitagawa finds a foreign student distraught and crying because her father had said that he hated Japanese people (Nihonjin kirai). The girl's ethnicity and grade level change each time Kitagawa tells the story;

\footnotetext{
${ }^{2}$ All translations in this paper are my own.
} 
however, the depiction of the father's supposed hatred for the Japanese remains constant, and positions him as a barrier to his daughter's otherwise smooth assimilation in Japan.

\section{Oaths and Tests}

Teachers' general distrust of foreign parents further reveals itself in two recurring issues: the school's oath requirement for foreign parents, and teachers' repeated questioning of parents' future migration plans. The written oath (seiyakusho) was implemented to address the supposed problem of foreign parents not committing to following school rules. ${ }^{3}$ The oath lists 11 general school rules, including contacting the school when children would be absent or late, having children walk in their assigned groups to and from school, making their children study at home, and paying monthly school fees on time. Every year, foreign parents sign the oath, affirming "To the principal of Shiroyama Elementary School, I want to enroll my child in the school. I affirm that I will respect the school rules, and in the event that I violate the rules, I will respect the school's decision." There is no Japanese version of this oath, because, as one teacher claims, the Japanese parents already know to follow these rules-even though teachers have to call Japanese homes almost daily to check on unexplained absences.

Teachers praise the supposed efficacy of the oath in changing foreign parents' behavior; however, the causal impact of the oath is unclear, as parents were asked to sign a poorly legible photocopy of a handwritten Spanish oath that contained grammatical and spelling errors. The school also has no Portuguese, Mandarin, Tagalog, or English versions of the oath, perhaps due

\footnotetext{
3 Tsuneyoshi (2001:132) notes the use of a similar document in a 1991 guidebook for foreign parents at another public school in Japan. There is a historical precedent for the use of oaths in the postwar treatment of resident Koreans in Japan. Parents who wished to enroll their children in Japanese public schools were required to sign an oath that read "Upon enrolling our child in this school, we will agree to abide by Japanese laws and never to burden the school with the cost of our child's education. If we breach this agreement, we will not object to our child's expulsion from the school" (Sakuma 2006, as quoted in Kanno 2008:16).
} 
to the predominance of Spanish speakers among the school's foreign population. Nonetheless, some teachers refer to the oath when problems or misunderstandings occur, complaining that parents are not keeping their promises to follow the rules (yakusoku wo mamotte kurenai). Extending this logic, teachers contend that parents who do not keep their word on small matters, like calling the school when their child is absent, cannot be trusted to commit to something larger, like assimilating into Japanese society.

In addition to using the oath, teachers also question parents about their future migration plans. Nearly every parent-teacher conference starts with teachers asking whether the families are returning to Peru or staying in Japan. With few exceptions, parents consistently answer that they are planning to remain in Japan. The only trips to Peru, parents explain, will be "de visita" (for a visit). Each year several families travel to Peru during the school's winter break. During these trips, parents visit relatives not seen for years, and children see their grandparents, sometimes for the first time. The high cost of these trips limits families to traveling about once a decade, with some families having never visited Peru since arriving in Japan more than 20 years ago.

As with many migrant groups traveling back to their home countries, Peruvian parents see these trips as important opportunities to instill a Peruvian identity in their children. Many of these children feel more connected to Japan than Peru, to the point of seeing themselves as ethnic Japanese. In trying to instill a Peruvian identity, the parents seek to protect their children from the disappointment they themselves experienced when they were treated in Japan as gaijin and not as Japanese descendants (cf. Takenaka 2004, 2008; Tsuda 2000, 2003). Parents also hope that travel to Peru will counter the cultural distance between them and their 
children, as their children acculturate to Japanese norms and Japanese becomes the children's primary language.

In public, teachers are supportive of the trips, saying that family ties are important. However, in private, teachers react as if the trips were a betrayal and represented parents' lack of commitment to living in Japan. ${ }^{4}$ This resentment can be seen in comments made by Watanabe-sensei, who asks me why Makoto, a student in his class, had left school to travel to Peru. "What do they do when they go back? ... Live regular lives? Are they playing?" I tell Watanabe the story Makoto's mother had shared with me, that they had not visited Peru for ten years, that her father, whom Makoto had never met, would not live much longer, and this was the family's last chance to visit Peru for many years. While I feel I am telling a sad, moving story about long-distance family separation, Watanabe seems dissatisfied and unhappy that the families would go back to Peru.

Is that so. The nationality for over there is something that's really important to them, isn't it. They came here to earn money. ... I wonder what they're doing. I thought they were simply going back to their hometown, but somehow, to say it badly, they go there to play and then they come back, and then here they work, and then they go back there to play. That's a bad way of looking at that lifestyle. I don't really think that's very good. They have different reasons, but, that's what I think.

Watanabe does not frame his concerns in terms of impacts on students' academic performance, as some teachers do. Rather, he describes a life of circular migration, with Peruvian families having no more commitment to living in Japan than to make money to send back to Peru, where they will eventually return. However, that does not describe the Peruvian families in

\footnotetext{
${ }^{4} 100$ years earlier, Nikkeijin in Peru faced a similar reaction when they tried to sustain ties to Japan. For Peruvians, this constituted "an act of betrayal and a sign of anti-Peruvian militancy" (Takenaka 2004:87). 
Watanabe's class. Makoto is a strong student, outperforming some of his Japanese classmates, and his family has expressed their commitment to permanently residing in Japan.

Despite parents' consistency in describing their long-term plans, teachers often doubt the veracity of parents' statements. "What do they want to do? I don't know what problems they're having," complains Yoshida-sensei.

[T] hese South Americans, do they want to go back over there, do they want to stay here, there's no expression of their intentions, none at all. How should we teach them? For example, are they here temporarily to work and then they'll go back? Then it's not necessary to teach them the Japanese language or Japanese education. They can come to school and make friends with the Japanese kids, but no, if they're going to stay in Japan, then they have to study. And go to high school and a university. That path and thinking about the future, somehow, they only partially hear it. I haven't had a slow and careful conversation with them about it. How should we deal with it, what advice do we give, I don't know.

Other teachers share Yoshida's frustrations, complaining that they are unsure whether to teach foreign children kanji (Chinese ideographs), or to focus more on lessons that could be useful in Peru, such as mathematics. Thus, in asking parents about their migration plans, teachers are both questioning parents' commitment to living in Japan and seeking clarification of their role in teaching the children. In contrast, parents worry that the school is reproducing their marginal status by tracking their children into less rigorous work because teachers think the children will leave the country. Thus, parents do not discuss any uncertainty in their future plans, and they plead with the teachers to teach their children more Japanese.

\section{Calling in the Community}

When foreign parents do not comply with teachers' efforts, some teachers resort to contacting others in the community for assistance. As noted previously, contact between the school and community members is not unusual (Moorehead 2007; White 1987). School 
policies prohibit teachers from sharing confidential information; however, some teachers violate these policies by discussing families' private matters with employers and others in the community. In one instance, Kitagawa-sensei telephones the employer of Hikaru's mother to request that the employer investigate Hikaru's comment that his mother is pregnant.

The child, Hikaru, says his mother is pregnant. Now, the father isn't there, and Hikaru is a first-grade student, so this is a school matter. Is she getting married, is she getting divorced, that kind of thing, it has to do with the child. This is important, and I want information.

Based on a teacher's claim that Hikaru had once said he was hungry, Kitagawa also asks the employer to look into whether the mother is abusing her son by not feeding him. Despite teachers' claim that they are involving people in the neighborhood because they have a shared responsibility in raising the children, during my fieldwork teachers only took this step when dealing with foreign children. Hikaru's mother also describes these calls as spurring gossip among co-workers in the factory. "The things that reach the office, everyone in the factory knows them. Whatever happens, everyone knows about it," she explains.

\section{IMPACTS ON PERUVIAN ASSIMILATION}

Involving the community in these matters usurps Peruvian parents' authority over their children, and reinforces the teachers' position of power over the parents. The parents are further restricted by the fact that they cannot enroll their children in a different public elementary school. Hemmed in by limited language skills, calls to their employers and neighbors, and the inability to change schools, parents acquiesce. Some have challenged teachers and loudly questioned their treatment of foreigners, however these exchanges have 
merely reinforced the parents' outsider status. "There's nothing you can do about it. You have to keep gambateando (fighting)," says Hikaru's mother in a mix of Spanish and Japanese.

Here, I can't speak [Japanese], I don't even have the chance to say that I don't like the teacher, how she treats the kids, because I don't know the language, one, also because I can't change schools because I live in Shiroyama, so I have to take [my son] to that school. There's nothing I can do about it. So, as they say, I have to put up with it.

In conversations and interviews, Peruvian parents openly discuss their bitterness over how teachers treat them. Like the teachers' discourse about the foreign parents, the parents mainly talk about the school in negative terms. The parents' position as outsiders to their children's Japanese education, and their heavy reliance on the school for preparing their children for life in Japan are recurrent themes in this discourse. Nonetheless, parents feel the responsibility to adapt falls more on them than on their children. Angelica, the mother of a child in the sixth grade, explains:

Comparing it to your own country, it's so different, and sometimes so ridiculous. ... We just have to adapt, because they [the children], it's not that they have to adapt, ya son (they already are) [Japanese]. We're the ones who have to adapt, the parents, because they're already there, they see things as if that's the way they really are.

Despite feeling this pressure to adapt, parents are distrustful of the school, unhappy with their children's academic progress, and unsure how to raise concerns or make changes.

Parents also connect their treatment at the school with the broader challenges of integrating into Japanese society. Juan, a father of two school-age children, notes the barriers that Peruvians face in gaining greater acceptance and integration in Japan:

For example, what I see in the factory, the highest position you could get is leader. Leader of who? The Japanese? No. Leader of the foreigners, foreigners like Brazilians, Paraguayans, and others. But here I can't achieve more, I'm never 
going to achieve more. I'm never going to be a permanent [employee]. So that whole situation, it's not resentment toward the Japanese, because my father and mother were Japanese, if they weren't I wouldn't be here. But it's ... more that the Japanese need to be more open toward foreigners ....

In response to this perceived lack of openness, parents are resisting by assimilating more selectively. This involves learning what they think they need to know to live in Japan, such as gaining basic language skills and understanding the education system so they can prepare their children, while setting limits on that assimilation. Juan states that without an environment of acceptance and inclusion, he and his wife, Lucía, avoid trying to further integrate into Japanese society. Instead, he says that they have just "semi-adapted":

What we do is, we haven't gotten used to it, we've semi-adapted. Semi. ... My wife and I are more included, semi-included, in Japanese society than others. Why? Because of our physical features and our last name [which are Japanese].

For Juan, this "semi-adapting” enables him and Lucía to claim a sense of agency by setting the terms of their future assimilation. To the extent that Japan opens up to them, they will respond in kind. However, until then, Juan says they have stopped assimilating.

Japan's other major migrant group from South America, Brazilian Nikkeijin, have responded similarly, by expressing a deterritorialized nationalism (Tsuda 2010) in which they convey their Brazilian identity by wearing Brazilian-style fashion, dancing samba, and displaying the Brazilian flag-activities few engaged in prior to migrating to Japan. Some Peruvians also feel a renewed national bond and proudly don t-shirts emblazoned with the name of their home country. However, even in Shiroyama where Peruvians are the majority of the foreign population, the Peruvian flag is displayed infrequently. This may reflect the ambivalence many Nikkeijin feel regarding their status in Peru, where their Peruvian-ness was 
routinely questioned. Many note the irony that in Peru they were told they were Japanese and not Peruvian, while in Japan they have been told they are Peruvian and not Japanese. Being treated as outsiders in both countries weakens their sense of national belonging, leading one parent to say the Nikkeijin do not have a homeland, but instead exist somewhere in the clouds. Despite this pessimism, Peruvian parents are open to more positive relations in Japan, and speak warmly about instances of Japanese adapting to their presence and to their culture, including adopting the Peruvian custom of public displays of affection. They also praise other Japanese schools where they feel they were better accommodated and made to feel welcome.

\section{CONCLUSION}

The parents' strategy of holding out for greater acceptance by the Japanese might serve as a psychic bulwark against a hostile environment in which being Peruvian is seen as a problem (Du Bois 1903; Lewis 2003); however, this strategy is unlikely to facilitate integration in Japan. As Tsuda (2000:68) notes:

The ethnic resistance of the nikkeijin does not produce any economic or political benefits. On the contrary, it reinforces their socioeconomic subordination in Japan by ensuring that they remain a culturally different and unassimilated immigrant minority which will continue to be socially marginalized by the Japanese.

This resistance also risks fulfilling the negative expectations of the teachers' ethnic project, which defines Peruvian parents as disloyal outsiders. In response, teachers are likely to present renewed complaints, advancing the cycle of hostility (Bonacich 1973; Takenaka 2004) between parents and teachers. However, Peruvian resistance is not only about socioeconomic goals, but also about the role of ethnic difference in contemporary Japan (cf. Appadurai 1996:14). As Juan notes, Peruvians seek inclusion and chafe at being only semi-included. Thus, asserting their 
Peruvian-ness and holding back from trying to assimilate further is about seeking "recognition," which Lie (2008:80) defines as "a complex of attributes—love, right, and esteem— that endow people with a sense of acceptance and acknowledgement" as full members of the nation-state. This acceptance and acknowledgement also extends to recognizing the shared humanity of Peruvians and Japanese (cf. Fanon 1967; Tsuda 2000).

Research has repeatedly shown that stronger, more positive ties between immigrant parents and host-country teachers can promote more consonant acculturation in immigrant families, and enable parents' to feel greater trust and belonging in the new society (Kasinitz et al. 2008; Portes and Rumbaut 1996, 2001; Portes and Zhou 1993; Zhou and Bankston 1998). However, a more negative context of reception, in which being an immigrant is seen as a problem, risks fomenting reactive ethnicities and oppositional identities (Du Bois 1903; Lewis 2003; Portes and Rumbaut 1996, 2001), as immigrants cling more strongly to a minority identity, frame the host-country identity in negative terms, and reject mainstream host-country values. The process of creating the disloyal alien defines the meaning of Japanese and Peruvian identities in this relatively new inter-group relationship. Those meanings, in turn, influence the relationship between the two groups (Moorehead 2012, 2013; Omi and Winant 1994:61). The ethnic project has less to do with explaining ethnic or cultural differences than with a dominant group creating social distance, and then using that distance against the groups it want to distance itself from (Blumer 1958; Memmi 1968; Omi and Winant 1994). Examining this process also reveals how the paths to unequal future outcomes are structured, as Peruvian marginalization in Japan may inhibit the group's academic and occupational mobility. 
Peruvian parents remain open to the possibility of a more positive future in Japan, but are highly skeptical that such a future will happen. They complain that real inclusion, not semiinclusion, is a two-way street (cf. Massey and Sánchez R. 2010:2), in which both immigrants and members of the host society adapt to each others' presence. First-generation Peruvians in Japan continue to hold out for the Japanese to adapt. Selective assimilation can be a successful assimilation strategy that allows immigrant families to draw on the resources of both immigrant and host-country communities, and balance both cultures (Portes and Rumbaut 1996, 2001). However, achieving this balance is complicated by the fact that the second generation has adapted to the point that many children self-identify as Japanese. As Angelica notes, the children already are Japanese, at least in terms of culture and language.

Teachers' negative treatment of the parents as disloyal outsiders in Japan may also be structuring future paths to inequality, by encouraging Peruvian children to reject their parents' ethnicity in favor of that of the host society (e.g., Kasinitz et al. 2008; Portes and Rumbaut 2001). This can be seen as Peruvian children cringe when their parents speak to them in Spanish in public, and point out others as being Peruvian while seeing themselves as Japanese. In so doing, the children may be simply following their teachers' lead, as teachers question the parents' commitment to living in Japan and define being Peruvian as a problem. The combination of children's assimilation, the framing of Peruvian-ness as a problem, and the parents' resistance to further assimilation risks increasing generational dissonance within the families (Portes and Rumbaut 1996, 2001). Parents try to keep this dissonance in check by telling the children they are Peruvian and not Japanese, by speaking to the children in Spanish, and by traveling back to Peru. Despite these efforts, the pressures on the children to assimilate 
are strong, particularly in Japanese schools, where ethnic minority students are often pressured to blend in and avoid standing out in the classroom setting (LeTendre, Hofer, and Shimizu 2003; Moorehead 2012, 2013; Shimizu 1992, 2001; Shimizu et al. 1999; Tsuneyoshi 1996, 2001). This assimilative distance between the children and their parents may also exacerbate the parents' feelings of homelessness, as they find themselves in exile (Lie 2008), rejected by both Peru and Japan and lacking the sense of belonging that comes from having a homeland.

These findings highlight the prospective nature of race and ethnicity by showing how present-day social relations can lay the groundwork for unequal relations in the future. Thus race and ethnicity are not pre-existing categories, but processes by which groups create and maintain social distance (Blumer 1958; Memmi 1968; Omi and Winant 1994). Immigrants' assimilation paths are shaped not only by the context of reception (Portes and Rumbaut 1996, 2001), but also by the relations of power and domination that define each group's status in the host society (Jung 2004). Understanding the processes by which each group's status is negotiated and defined, through racial and ethnic projects, can reveal the specific mechanisms through which group categories are defined and resisted. 


\section{WORKS CITED}

Appadurai, Arjun. 1996. Modernity at Large: Cultural Dimensions of Globalization. Minneapolis: University of Minnesota Press.

Blumer, Herbert. 1958. "Race Prejudice as a Sense of Group Position." Pacific Sociological Review $1(1): 3-7$.

Bonacich, Edna. 1973. "A Theory of Middleman Minorities.” American Sociological Review 38(5): 583-594.

Du Bois, W. E. Burghardt. 1903. The Souls of Black Folk: Essays and Sketches. Cambridge, MA: University Press.

Fanon, Frantz. 1967. Black Skin, White Masks. Translated by C. L. Markmann. New York: Grove Press.

Fox, Jon E. 2007 “From National Inclusion to Economic Exclusion: Ethnic Hungarian Labour Migration to Hungary." Nations and Nationalism 13(1): 77-96

Goffman, Erving. 1963. Stigma: Notes on the Management of Spoiled Identity. New York: PrenticeHall.

Golash-Boza, Tanya. 2006. "Dropping the Hyphen? Becoming Latino(a)-American through Racialized Assimilation." Social Forces 85(1):27-55.

Gurowitz, Amy. 2006. “Looking Outward: International Legal Norms and Foreigner Rights in Japan.” Pp. 153-171 in Local Citizenship in Recent Countries of Immigration: Japan in Comparative Perspective, edited by T. Tsuda. Lanham, MD: Lexington Books. 
Higuchi, Naoto and Kiyoto Tanno. 2003. "What's Driving Brazil-Japan Migration? The Making and Remaking of the Brazilian Niche in Japan." International Journal of Japanese Sociology 12:33-47.

Higuchi, Naoto. 2010. "Keizai kiki to zainichi burajirujin (Economic Crisis and Zainichi Brazilians)." Ōhara Shakai Mondai Kenkyujo Zasshi (Journal of the Ōhara Institute for Social Research). 622:50-66. Tokyo: Ohara Shakai Mondai Kenkyujo.

Jung, Moon-Kie. 2004. “The Racial Unconscious of Assimilation Theory.” Du Bois Review 6(2): 375-395.

Kanno, Yasuko. 2008. Language and Education in Japan: Unequal Access to Bilingualism. New York: Palgrave Macmillan.

Kasinitz, Philip, John H. Mollenkopf, Mary C. Waters, and Jennifer Holdaway. 2008. Inheriting the City: The Children of Immigrants Come of Age. Cambridge, MA: Harvard University Press.

King, Russell, and Anastasia Christou. 2010. "Cultural Geographies of Counter-Diasporic Migration: Perspectives from the Study of Second-Generation 'Returnees' to Greece." Population, Space and Place 16:103-119.

LeTendre, Gerald K., Barbara K. Hofer, and Hidetada Shimizu. 2003. "What Is Tracking? Cultural Expectations in the United States, Germany, and Japan.” American Educational Research Journal 40:43-89.

Lewis, Amanda E. 2003. Race in the Schoolyard: Negotiating the Color Line in Classrooms and Communities. New Brunswick, NJ : Rutgers University Press.

Lie, John. 2008. Zainichi (Koreans in Japan): Diasporic Nationalism and Postcolonial Identity. Berkeley: University of California Press. 
Lofland, John, David Snow, Leon Anderson, and Lyn H. Lofland. 2006. Analyzing Social Settings: A Guide to Qualitative Observation and Analysis. 4th ed. Belmont, CA: Wadsworth.

Massey, Douglas, and Magaly Sánchez R. 2010. Brokered Boundaries: Creating Immigrant Identity in Anti-Immigrant Times. New York: Russell Sage Foundation.

Memmi, Albert. 1968. Dominated Man: Notes toward a Portrait. New York: Orion Press.

Ministry of Education, Culture, Sports, Science, and Technology [MEXT]. 2013. "Nihongo Shidō Ga Hitsuyō Na Jidō Seito Jōkyō Nado Ni Kansuru Chōsa (Surveys on the Status of Children Needing Japanese Language Instruction and Related Matters).” Retrieved July 29, 2013 (http://www.e-stat.go.jp/SG1/estat/List.do? bid $=000001047825 \&$ cycode $=0)$.

Ministry of Health, Labour, and Welfare. 2009. "Nikkeijin Rishokusha Ni Taisuru Kikoku Shien Jikyō No Gaiyō (Outline of the Project Supporting the Repatriation of Unemployed Nikkeijin)." Retrieved April 1, 2009 (http://www.mhlw.go.jp/houdou/2009/03/dl/ h0331-10a.pdf).

Ministry of Health, Labour, and Welfare. 2012 "Kikoku Shien Jigyo No Jisshi Ni Tsuite (The Repatriation Program for Nikkeijin).” Retrieved December 15, 2012 (http://www. mhlw.go.jp/houdou/2009/03/h0331-10.html).

Ministry of Justice. 2013. "Zairyū Gaikokujin Tōkei (Kyūtōroku Gaikokujin Tōkei) Tōkeihyō (Resident Foreigner Statistics (Former Resident Registration) Sheet).” Retrieved July 29, 2013 (http://www.moj.go.jp/housei/toukei/toukei_ichiran_touroku.html). 
Moorehead, Robert. 2007. “Ethnic Boundary Enforcers: Conceptualizing Japanese Teachers’ Treatment of Migrant Latino Parents." Shakai Fukushi Kenkyū (Social Welfare Studies) 9:77-87.

Moorehead, Robert. 2012. "Remedial Language Education and Citizenship: Examining the JSL Classroom as an Ethnic Project." Pp. 98-116 in Language and Citizenship in Japan, edited by N. Gottlieb. London: Routledge.

Moorehead, Robert. 2013. "Separate and Unequal: The Remedial Japanese Language Classroom as an Ethnic Project.” The Asia-Pacific Journal 11(32):3. Retrieved August 4, 2013 (http:// japanfocus.org/-Robert-Moorehead/3980).

Omi, Michael, and Howard Winant. 1994. Racial Formation in the United States: From the 1960s to the 1990s. 2nd ed. New York: Routledge.

Portes, Alejandro, and Min Zhou. 1993. "The New Second Generation: Segmented Assimilation and Its Variants." The Annals of the American Academy of Political and Social Science 530:74-96.

Portes, Alejandro, and Rubén G Rumbaut. 1996. Immigrant America: A Portrait. Berkeley: University of California Press.

Portes, Alejandro, and Rubén G. Rumbaut. 2001. Legacies: The Story of the Immigrant Second Generation. Berkeley: University of California Press.

Sakuma, Kosei. 2006. Gaikokujin No Kodomo No Fushūgaku (Non-School Enrollment of Foreign National Children). Tokyo: Keisō Shobō.

Shimizu, Kokichi. 1992. "Shido: Education and Selection in a Japanese Middle School." Comparative Education 28:109-129. 
Shimizu, Kokichi. 2001. "The Pendulum of Reform: Educational Change in Japan From the 1990s Onwards." Journal of Educational Change 2:193-205.

Shimizu, Kokichi, Akira Sakai, Mutsumi Shimizu, and Izumi Dotera. 1999. "Invisible Foreigners: The Japanese School Culture and the 'Newcomer' Children.” Tokyo Daigaku Daigakuin Kyōiku Gaku Kenkyūka Kiyō (Tokyo University Graduate Faculty of Education Research Seminar) 39:339-364.

Statistical Research and Training Institute. 2010. Japan Statistical Yearbook 2010. Tokyo: Statistics Bureau.

Takenaka, Ayumi. 2004. “The Japanese in Peru: History of Immigration, Settlement, and Racialization." Latin American Perspectives 31(136):77-98.

Takenaka, Ayumi. 2008. "How Diasporic Ties Emerge: Pan-American Nikkei Communities and the Japanese State." Ethnic and Racial Studies 31(1):1-21.

Takenaka, Ayumi. 2014. “The Rise and Fall of Diasporic Bonds in Japanese-Peruvian 'Return' Migration.” International Migration. Retrieved March 26, 2014 (http://doi.wiley.com/ 10.1111/imig.12147).

Takenoshita, Hirohisa. 2006. “The Differential Incorporation Into Japanese Labor Market: A Comparative Study of Japanese Brazilians and Professional Chinese Migrants." The Japanese Journal of Population 4:56-77.

Tsuda, Takeyuki. 2000. "Acting Brazilian in Japan: Ethnic Resistance among Return Migrants.” Ethnology 39(1):55-71.

Tsuda, Takeyuki. 2003. Strangers in the Ethnic Homeland: Japanese Brazilian Return Migration in Transnational Perspective. New York: Columbia University Press. 
Tsuda, Takeyuki, ed. 2009. Diasporic Homecomings: Ethnic Return Migration in Comparative Perspective. Palo Alto, CA: Stanford University Press.

Tsuda, Takeyuki. 2010. "Ethnic Return Migration and the Nation-State: Encouraging the Diaspora to Return 'Home." Nations and Nationalism 16(4):616-636.

Tsuda, Takeyuki, Zulema Valdez, and Wayne Cornelius. 2003. "Human Capital Versus Social Capital: Immigrant Wages and Labor Market Incorporation in Japan and the United States." Migraciones Internacionales 2:5-35.

Tsuneyoshi, Ryōko. 1996. “Tabunka Kyōson Jidai No Nihon No Gakkō Bunka” (Japanese School Culture in an Era of Multicultural Coexistence). Pp. 215-240 in Kōza Gakkō 6: Gakkō Toiu Jijō (Lecture School 6: A Field Called the School), edited by T. Horio. Tokyo: Kashiwa Shobo.

Tsuneyoshi, Ryōko. 2001. The Japanese Model of Schooling: Comparisons with the United States. New York: Routledge.

White, Merry I. 1987. The Japanese Educational Challenge: A Commitment to Children. New York: Free Press.

Williams, Raymond. 1977. Marxism and Literature. New York: Oxford University Press.

Zhou, Min, and Carl L Bankston. 1998. Growing Up American: How Vietnamese Children Adapt to Life in the United States. New York: Russell Sage Foundation. 